\title{
EFFECTS OF CIRCULATING FLUIDIZED BED COMBUSTION FLY ASH ON THE PROPERTIES OF ALKALI-ACTIVATED SLAG CEMENT MORTARS
}

Hui-Mi Hsu

Department of Civil Engineering, National Ilan University, Ilan City, Taiwan, R.O.C, hmhsu@niu.edu.tw

Follow this and additional works at: https://jmstt.ntou.edu.tw/journal

Part of the Other Civil and Environmental Engineering Commons

\section{Recommended Citation}

Hsu, Hui-Mi (2012) "EFFECTS OF CIRCULATING FLUIDIZED BED COMBUSTION FLY ASH ON THE PROPERTIES OF ALKALI-ACTIVATED SLAG CEMENT MORTARS," Journal of Marine Science and Technology. Vol. 20: Iss. 2, Article 14. DOI: $10.51400 / 2709-6998.1842$

Available at: https://jmstt.ntou.edu.tw/journal/vol20/iss2/14

This Research Article is brought to you for free and open access by Journal of Marine Science and Technology. It has been accepted for inclusion in Journal of Marine Science and Technology by an authorized editor of Journal of Marine Science and Technology. 


\title{
EFFECTS OF CIRCULATING FLUIDIZED BED COMBUSTION FLY ASH ON THE PROPERTIES OF ALKALI-ACTIVATED SLAG CEMENT MORTARS
}

\author{
Hui-Mi Hsu
}

Key words: circulating fluidized bed combustion, fly ash, alkali activator, slag, cement, mortar.

\begin{abstract}
This paper illustrates the result of a study on the influence of circulating fluidized bed combustion (CFBC) fly ash, sodium hydroxide $(\mathrm{NaOH})$, sodium silicate $\left(\mathrm{Na}_{2} \mathrm{SiO}_{3}\right)$, sodium phosphate $\left(\mathrm{Na}_{3} \mathrm{PO}_{4}\right)$, and sodium carbonate $\left(\mathrm{Na}_{2} \mathrm{CO}_{3}\right)$ as activators on the workability, bleeding, setting time, compressive strength, shrinking, and absorption of the alkali-activated slag (AAS) cement mortars. The addition of CFBC fly ash, $\mathrm{Na}_{3} \mathrm{PO}_{4}$, and $\mathrm{Na}_{2} \mathrm{CO}_{3}$ shows decrease of workability. But with $\mathrm{Na}_{2} \mathrm{SiO}_{3}$, the workability increase was observed. The setting time of $\mathrm{Na}_{3} \mathrm{PO}_{4}, \mathrm{NaOH}, \mathrm{Na}_{2} \mathrm{SiO}_{3}$, and $\mathrm{Na}_{2} \mathrm{CO}_{3}$ activated slag cement mortars was found to be much faster than the setting time of slag cement mortars. Slag cement mortars activated with CFBC fly ash show similar strength properties to slag cement mortars. CFBC fly ash activated slag cement mortars gained higher early compressive strength and developed 50MPa compressive strength at the age of 56 days. CFBC fly ash activated slag cement mortars were found providing higher compressive strength than other activated slag cement mortars.
\end{abstract}

\section{INTRODUCTION}

Energy saving and carbon reduction are encouraged by everyone in the world recently, thus the concept of sustainable development is getting popular. People around the world increase emphasis on environmental protection. As a result, recycle and reuse of industrial by-products becomes the direction of state-of-the-art research. Currently, a wide range of construction industrial by-products are used, e.g., fly ash, silica fume, and water quenching slag, to replace the amount of cementing material for reducing cement consuming. Cir-

Paper submitted 03/18/11; revised 05/20/11; accepted 06/22/11. Author for correspondence: Hui-Mi Hsu (e-mail: hmhsu@niu.edu.tw).

Department of Civil Engineering, National Ilan University, Ilan City, Taiwan, R.O.C. culating Fluidized Bed Combustion (CFBC) has been developing as a new burning technique for the past 20 years, which possesses the characteristics of broad fuel adaptability, low pollution, and high efficient combustion [11, 16]. CFBC makes use of $\mathrm{CaO}$ as the desulfurization admixture, and mixes fuel and limestone directly before send them into the boiler for burning. The electrostatic precipitator equipment collected the particles called fly ash. The fly ash called CFBC fly ash, which contains a strong property of alkali. In recent years, the domestic industries actively seek for the new burning technique improvement to solve the problem comes from reusing the high sulfur content petroleum coke (sulfur content $>6 \%$ ) as fuel, therefore the technology of CFBC is introduced.

The use of alkali activator in cement and concrete as a cement constituent material can be traced back to 1930, when Kuhl studied the condensation mixture of the silica slag powder and the potassium hydroxide solution. In 1940, Purdon conducted a series tests on the composition of cement clinker by mixing slag and sodium hydroxide as well as slag, alkali, and alkaline salts in the laboratory at the start [15]. Glukhovsky found that the cement materials can be obtained from the productions of used silica aluminate with or without calcium and alkali metal solution in 1957. In 1981, Davidovitsru obtained cement materials by mixing the kaolinite burning-off, limestone, dolomite mixture, and alkali solution [12]. Since then, many countries began to carry out extensive research on alkali-activated cement and concrete and its application on construction projects.

The alkali activated slag (AAS) has features of cost reducing, high strength, low hydration heat, low porosity, low water-soluble hydrate, and high resistance to chemical attack capability. Commonly used alkali activators include $\mathrm{NaOH}$, $\mathrm{SiO}_{2}, \mathrm{CO}_{2}$, and $\mathrm{SO}_{3}$, which $\mathrm{Na}_{2} \mathrm{SiO}_{3}$ and Sodium silicate $\left(\mathrm{SO}_{3}-\right.$ and $\mathrm{HSiO}_{3}^{-}$) are the most effective activators. It has been proposed by previous research results that the AAS has the problems of quick setting time and high drying shrinkage [10, 13]. This paper focuses on the CFBC fly ash to be alkali activator, which is produced by using the petroleum coke as the fuel, and studies the benefits of using CFBC fly ash to be alkali activated slag. 
Table 1. Chemical composition (\%) of cement, slag, and CFBC fly ash.

\begin{tabular}{cccc}
\hline Chemical composition & Cement & Slag & CFBC fly ash \\
\hline $\mathrm{SiO}_{2}$ & 20.60 & 34.4 & 3.72 \\
$\mathrm{Al}_{2} \mathrm{O}_{3}$ & 4.00 & 9.0 & 0.55 \\
$\mathrm{Fe}_{2} \mathrm{O}_{3}$ & 6.10 & 2.58 & 0.57 \\
$\mathrm{CaO}$ & 62.80 & 44.8 & 55.84 \\
$\mathrm{MgO}$ & 2.60 & 4.43 & 1.62 \\
$\mathrm{~K}_{2} \mathrm{O}$ & --- & 0.50 & 0.34 \\
$\mathrm{Na}_{2} \mathrm{O}$ & --- & 0.62 & 0.10 \\
$\mathrm{SO}_{3}$ & 3.10 & 2.26 & 29.09 \\
$\mathrm{TiO}_{2}$ & --- & --- & --- \\
\hline
\end{tabular}

\section{EXPERIMENTAL PROGRAM}

\section{Material Properties}

This study aims to investigate the mechanical and hydration characteristics of cement base material containing CFBC fly ash and other alkali activators as well as alkali-activated slag. Materials sources and characteristics used in this study, including cement, fine aggregate, CFBC fly ash, and a variety of alkali activators, are described as followed.

Cement. Type I Portland cement conforming to ASTM C150-09 [2] was used for all mixtures.

Fine Aggregate. The specific gravity (SSD) is 2.56, the water absorption is $2.25 \%$, and the fineness modulus of fine aggregate is 2.88 .

CFBC Fly Ash. CFBC fly ash is a white-color fine powder by-product from the Sixth Naphtha Cracker Plant of Formosa Petrochemical Corporation in Taiwan. The specific gravity CFBC fly ash is in the range of 2.5 2.7. The main chemical elements of CFBC fly ash are calcium (Ca), sulfur (S), and oxygen (O). The chemical compositions of CFBC fly ash are calcium oxide $(\mathrm{CaO})$, sulfur trioxide $\left(\mathrm{SO}_{3}\right)$, and a little silicon oxide $\left(\mathrm{SiO}_{2}\right)$. The mineral crystal phases of CFBC fly ash are $\mathrm{CaSO}_{4}$ (Anhydrite) and $\mathrm{CaO}$ (Lime). Table 1 demonstrates the chemical composition of cement, slag, and CFBC fly ash. CFBC fly ash comes from the device of the electrostatic precipitator collecting the industrial by-products generated form the circulating fluidized bed boiler combustion. Physical properties of the CFBC fly ash is similar to that generated from the general power coal combustion fly ash in appearance, fineness, grain size distribution, and packing density. However, the chemical natures are dissimilar to some extent, primarily due to $\mathrm{CFBC}$ fly ash has a higher free lime content (f-CaO), oxide sulfur content $\left(\mathrm{SO}_{3}\right)$, and calcium content $(\mathrm{CaO})$.

Sodium Carbonate $\left(\mathrm{Na}_{2} \mathrm{CO}_{3}\right)$. The chemical formula of sodium carbonate is $\mathrm{Na}_{2} \mathrm{CO}_{3}$ and also known as soda ash or washing soda. The sodium carbonate is defined as the content of more than $99 \% \mathrm{Na}_{2} \mathrm{CO}_{3}$ and is in the form of white powder under ordinary circumstances, which is a strong electrolyte. The density is $2.532 \mathrm{~g} / \mathrm{cm}^{3}$; the melting point is $851^{\circ} \mathrm{C}$; and the water solubility is $30 \mathrm{~g} / 100 \mathrm{ml}\left(\right.$ at $20^{\circ} \mathrm{C}$ ). The sodium carbonate can be natural mined or artificial production of anhydrous calcium carbonate without alkaline reaction. However, the sodium carbonate becomes alkaline once it is soluble in water.

Sodium Hydroxide (NaOH). The chemical formula of sodium hydroxide is $\mathrm{NaOH}$ and also known as lye and caustic soda, which is a caustic metallic base and is a strong chemical base. Pure sodium hydroxide can be white solid granules. It is very soluble in water with liberation of heat. Molten sodium hydroxide is also a strong base. It is insoluble in ether and other non-polar solvents. The density is $2.1 \mathrm{~g} / \mathrm{cm}^{3}$; the melting point is $318^{\circ} \mathrm{C}$; and the water solubility is $111 \mathrm{~g} / 100 \mathrm{ml}$ (at $\left.20^{\circ} \mathrm{C}\right)$.

Sodium Phosphate $\left(\mathrm{Na}_{3} \mathrm{PO}_{4}\right)$. The chemical formula of sodium phosphate is $\mathrm{Na}_{3} \mathrm{PO}_{4}$, which can be used as a cleaning agent, stain remover and degreaser. It is a white, granular or crystalline solid, highly soluble in water producing an alkaline solution.

Sodium Silicate $\left(\mathrm{Na}_{2} \mathrm{SiO}_{3}\right)$. The chemical formula of sodium silicate is $\mathrm{Na}_{2} \mathrm{SiO}_{3}$, with the common name for a compound sodium metasilicate. It is available in aqueous solution and in solid form and is used in cement frequently. The density is $2.4 \mathrm{~g} / \mathrm{cm}^{3}$; the melting point is $1088^{\circ} \mathrm{C}$; and the water solubility is quite high.

\section{Mix Proportions}

The water/cementitious material (cement + mineral materials) ratio is fixed at 0.5 for all mortar specimens in this study, while the replacing slag amount of the cement is also a fixed fraction (weight percent by replacing 50\%). The ratio of cementitious material to fine aggregate was 1:2.75, whereas the alkali activator was added with an extra amount. The extra amount of the CFBC fly ash is added by weight in accordance with different proportions, nevertheless the other alkali activators amount are calculated by the alkali equivalent. The mix design is shown in Table 2, where the term AG represents the control specimen.

\section{Specimens and Testing Methods}

Workability and Bleeding. The workability of mortar was evaluated according to ASTM D6103 [8]. The mortar sample was cast in the form of a bilateral cylindrical mold using a pilot hole, which is $75 \mathrm{~mm}$ in diameter and $150 \mathrm{~mm}$ in height. Bleeding tests were conducted in accordance with ASTM C232 [3].

Setting Time. Mortar setting time test was conducted according to ASTM C403 [4]. The values of penetration resistance in mortar that correspond to initial and final set in concrete were determined: These values were $3.5 \mathrm{MPa}$ for initial set and 26.7 MPa for final set.

Compressive Strength. To evaluate the strength development of cement mortar, this study conducted compressive strength tests in accordance with ASTM C109 [1] at 7, 28, 56 and 91 days. This test method covers determination of the compressive strength of hydraulic cement mortars, using $50 \mathrm{~mm}$ 
Table 2. Mix proportion for mortar specimens $\left(\mathrm{kg} / \mathrm{m}^{3}\right)$.

\begin{tabular}{cccccccccc}
\hline Mix & Water & Cement & Slag & Fine aggregate & CFBC fly ash & $\mathrm{NaOH}$ & $\mathrm{Na}_{2} \mathrm{CO}_{3}$ & $\mathrm{Na}_{2} \mathrm{SiO}_{3}$ & $\mathrm{Na}_{3} \mathrm{PO}_{4}$ \\
\hline AG & 267 & 267 & 267 & 1408 & - & - & - & - \\
\hline F10 & 267 & 267 & 267 & 1408 & 53 & - & - & - \\
F20 & 267 & 267 & 267 & 1408 & 106 & - & - & - \\
F30 & 267 & 267 & 267 & 1408 & 159 & - & - & - & - \\
\hline N3 & 267 & 267 & 267 & 1408 & - & 21 & - & - & - \\
N4 & 267 & 267 & 267 & 1408 & - & 28 & - & - \\
N5 & 267 & 267 & 267 & 1408 & - & 34 & - & - & - \\
\hline C3 & 267 & 267 & 267 & 1408 & - & - & 27 & - \\
C4 & 267 & 267 & 267 & 1408 & - & - & 37 & - & - \\
C5 & 267 & 267 & 267 & 1408 & - & - & 46 & - \\
\hline S3 & 267 & 267 & 267 & 1408 & - & - & - & 32 \\
S4 & 267 & 267 & 267 & 1408 & - & - & - & - \\
S5 & 267 & 267 & 267 & 1408 & - & - & - & - \\
\hline P3 & 267 & 267 & 267 & 1408 & - & - & - & - \\
P4 & 267 & 267 & 267 & 1408 & - & - & - & - \\
P5 & 267 & 267 & 267 & 1408 & - & - & - & - \\
\hline
\end{tabular}

cube specimens. After 24-hour curing, the specimens were demolded and placed in a water tank at room temperature until tested.

Drying Shrinkage. Prismatic mortar specimens with the dimensions of $25.3 \times 25.3 \times 284.6 \mathrm{~mm}$ were prepared for shrinkage measurement [5]. After demolding, the specimen was cured in water for 3 days, and then placed in a humidity cabinet at $23^{\circ} \mathrm{C}$ and $70 \% \mathrm{RH}$ until the age of 91 days. Initial length of all mortar specimens were measured before placing them into a humidity cabinet. Length measurements were performed after 7, 14, 21, 28, 56 and 91 days of storage.

Saturated Water Absorption. Saturated water absorption test was conducted according to ASTM C642 [6]. The size of the specimen is $\varphi 100 \times 50 \mathrm{~mm}$, oven dried test specimens were completely immersed in water, removed after two days of immersion, after wiping the surface with wet cloth then weighing again. Putting into the water for two days after the weighing, the weight of the latter with the former is less than $0.5 \%$ different, as a specimen of saturated state.

Initial Surface Absorption Test. The initial surface absorption test was carried out according to BS 1881 [9]. Fig. 1 illustrates the ISAT set-up. The test specimen was a cylinder of $100 \mathrm{~mm}$ (in diameter) and $50 \mathrm{~mm}$ (in length). The tests determined the rate of surface zone water absorption of the mortar samples during a prescribed period under a head of 200 $\mathrm{mm}$ of water. The rate of initial surface absorption is expressed in $\mathrm{ml} / \mathrm{ml}^{2}$-s.

Mercury Porosity. The distribution of pore size and pore volume were measured using a Micromeritics Autopore 9500 porosimeter. Mercury porosity test is performed according to ASTM D4404 [7]. Specimen size is a $10 \times 10 \times 10 \mathrm{~mm}$ cube. The device characterizes the mortar specimen's porosity by applying various levels of pressure to a sample immersed in

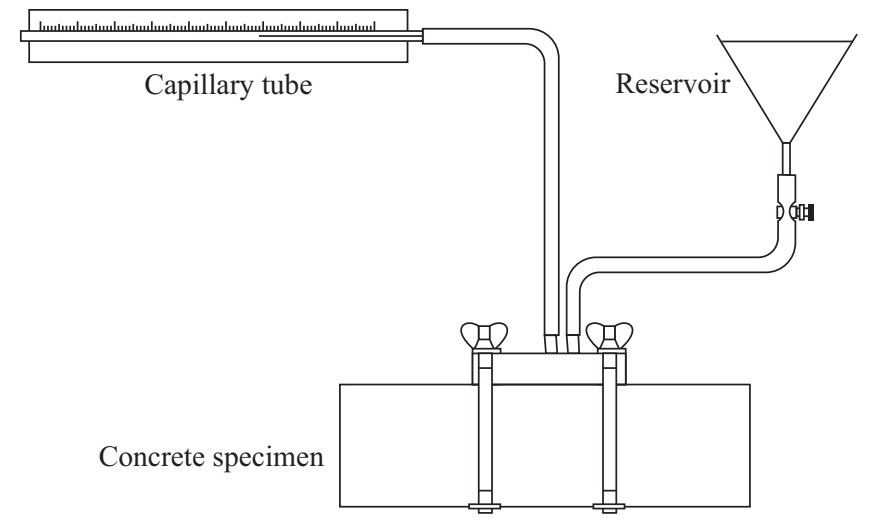

Fig. 1. Schematic ISAT arrangement.

mercury. The pressure required to intrude mercury into the specimen's pores is inversely proportional to the size of the pores. This is called mercury porosimetry, or often, "mercury intrusion".

SEM Observation. The Hitachi Model S-510 SEM was used for microstructure observation. The specimens with a dimension of $5 \mathrm{~mm}(\mathrm{l}) \times 5 \mathrm{~mm}(\mathrm{w}) \times 3 \mathrm{~mm}(\mathrm{t})$ were prepared by cutting a plate, which was $5 \mathrm{~cm}$ from the surface of the cylindrical specimens and oven-dried for 24 hours, pressure vacuumed up to 0.1 torr, and $\mathrm{Au}$-ion spotted for 2-3 min.

\section{RESULTS AND DISCUSSION}

\section{Freshly Mixed Mortar Properties}

Workability. The workability of the specimens is shown in Table 3 for using the alkali activator to stimulate slag. From the flow values of the specimens shown in Table 3, we can see 
Table 3. Properties of freshly mixed alkali activated slag mortar.

\begin{tabular}{crccc}
\hline Mix & $\begin{array}{r}\text { Flow } \\
(\mathrm{mm})\end{array}$ & $\begin{array}{c}\text { Initial setting } \\
\text { time }(\mathrm{min})\end{array}$ & $\begin{array}{c}\text { Finial setting } \\
\text { time }(\mathrm{min})\end{array}$ & $\begin{array}{c}\text { Bleeding } \\
\left(\mathrm{ml} / \mathrm{cm}^{2}\right)\end{array}$ \\
\hline AG & 9.43 & 223 & 449 & 0.0719 \\
\hline F10 & 8.62 & 213 & 444 & 0.0711 \\
F20 & 7.76 & 205 & 449 & 0.0134 \\
F30 & 7.44 & 161 & 404 & 0.0000 \\
\hline N3 & 8.83 & 93 & 230 & 0.0000 \\
N4 & 8.1 & 60 & 190 & 0.0000 \\
N5 & 8.01 & 45 & 171 & 0.0000 \\
\hline C3 & 7.72 & 123 & 236 & 0.0242 \\
C4 & 7.62 & 94 & 168 & 0.0077 \\
C5 & 7.38 & 70 & 209 & 0.0004 \\
\hline S3 & 16.28 & 58 & 237 & 0.0024 \\
S4 & 21.67 & 26 & 138 & 0.0043 \\
S5 & 24.61 & 24 & 137 & 0.0041 \\
\hline P3 & 8.71 & 83 & 180 & 0.0000 \\
P4 & 7.81 & 59 & 162 & 0.0000 \\
P5 & 8.33 & 77 & 169 & 0.0000 \\
\hline
\end{tabular}

that using CFBC fly ash as the alkali activator reduces the workability with the added amount because of the fine particle size of fly ash increasing the hydration rate. Adding $\mathrm{NaOH}$ as the alkali activator, the influence on the workability is not much with the adding amount increasing. Adding $\mathrm{Na}_{3} \mathrm{PO}_{4}$ as the alkali activator, the overall workability ranges are much lower than the control specimen, regardless of the added amount. Adding $\mathrm{Na}_{2} \mathrm{SiO}_{3}$ as the alkali activator, the addition can be clearly found that the workability significantly improved with the added amount increasing compared with the control specimen. Lastly, adding $\mathrm{Na}_{2} \mathrm{CO}_{3}$ as the alkali activator, there is not much significant changes of its workability with the added amount increasing. However, the added amount increases to $4 \%$ found the workability with the phenomenon of decline, while the added amount closes 5\%, the workability goes back to workability with the added amount of $3 \%$. This is because that $\mathrm{Na}_{2} \mathrm{CO}_{3}$ will accelerate the hydration reaction of cement. On the other hand, the workability declines when the added amount of $\mathrm{Na}_{2} \mathrm{CO}_{3}$ is higher caused by the phenomenon of retardation.

Bleeding. The bleeding reaction of the specimens is also shown in Table 3 for using the alkali activator to stimulate slag. From the bleeding values of the specimens shown in Table 3, we can see that using all kinds of alkali activators reduce the bleeding phenomenon. Adding CFBC fly ash, the bleed water reduces with the amount used. When the amount of CFBC fly ash reaches $30 \%$, there is no bleed water at all. Adding $\mathrm{Na}_{2} \mathrm{CO}_{3}$, the bleed water was also much less than the amount of control specimen. The reaction is the same with adding CFBC fly ash, which is reducing with the added amount increasing. Adding $\mathrm{NaOH}$ and $\mathrm{Na}_{3} \mathrm{PO}_{4}$, the effect of bleeding reduction is the most excellent, which performed almost no bleed water with the increasing added amounts. Adding $\mathrm{Na}_{2} \mathrm{SiO}_{3}$, the amount of bleed water increases with the added amount, but still much lowers than the control specimen. This is because that $\mathrm{Na}_{2} \mathrm{SiO}_{3}$ has the ability to bring the extra water in the mortar to the surface area, which can improve the workability on the other hand.

Setting Time. The setting time of the specimens is shown in Table 3 as well for using the alkali activator to stimulate slag. From the initial and final times of the specimens shown in Table 3, we can see that using all kinds of alkali activators reduce the setting times of the mortar specimens. Adding CFBC fly ash with the amount of $3 \%$ and $4 \%$ got the same results with those of control specimen. When the added amount reaches 5\%, the effect of time reduction became apparent. However, it is far from the phenomenon of quick setting time with the amount of 5\%. Adding $\mathrm{NaOH}$ obtained $45 \sim 93 \mathrm{~min}$ for initial setting time and 171 230 min for final setting time, which are both lower than the values of control specimen for $50 \%$. Adding $\mathrm{Na}_{3} \mathrm{PO}_{4}$, the final setting time was $162 \sim 180 \mathrm{~min}$ and the shortest in all specimens, which is about $1 / 3$ of the control specimen. Adding $\mathrm{Na}_{2} \mathrm{SiO}_{3}$, the initial setting time was 24 58 min and the shortest one in all specimens, which is only about surprisingly $10 \%$ of the control specimen. Adding $\mathrm{Na}_{2} \mathrm{CO}_{3}$, the setting times are about half of the values of control specimen. Altogether, all the alkali activators reduce the setting times because of the effect of hydration rate reduction.

\section{Physical Properties}

Saturated Water Absorption. Adding CFBC fly ash, the water absorption increases with the amount added as shown in Fig. 2. It is noted that the water absorption for $10 \%$ CFBC fly ash specimen began to reduce after 56 days and reached the same value of control specimen at the age of 91 days. Adding $\mathrm{NaOH}$, the added amounts made little difference on the water absorption, which are all higher than the control specimen as shown in Fig. 3. Adding $\mathrm{Na}_{3} \mathrm{PO}_{4}$, the added amounts also made little difference on the water absorption as shown in Fig. 4. The water absorption was higher than the control specimen in the early days while became close with the time went on. Adding $\mathrm{Na}_{2} \mathrm{SiO}_{3}$, the water absorption was much higher than the control specimen, but there is yet again no obvious relationship between the added amounts as shown in Fig. 5. Adding $\mathrm{Na}_{2} \mathrm{CO}_{3}$, the water absorption reduced with the added amount increasing as shown in Fig. 6, where the added amount of $\mathrm{Na}_{2} \mathrm{CO}_{3}$ to $5 \%$ was the closest to control specimen.

Drying Shrinking. Figs. 7 to 11 present the results of drying shrinkage of the mortar specimens with alkali activators and the control specimen. Adding CFBC fly ash, the drying shrinkage was about half value compared with the control specimen. The values are closer for added amounts of $10 \%$ and $20 \%$, while the value went high for $30 \%$ adding amount. It is significant to point out here that adding CFBC fly ash does not increase the amount of drying shrinkage of the mortar specimens, while all other kinds of alkali do. Adding $\mathrm{NaOH}$, the drying shrinking goes up with both the added amount and 


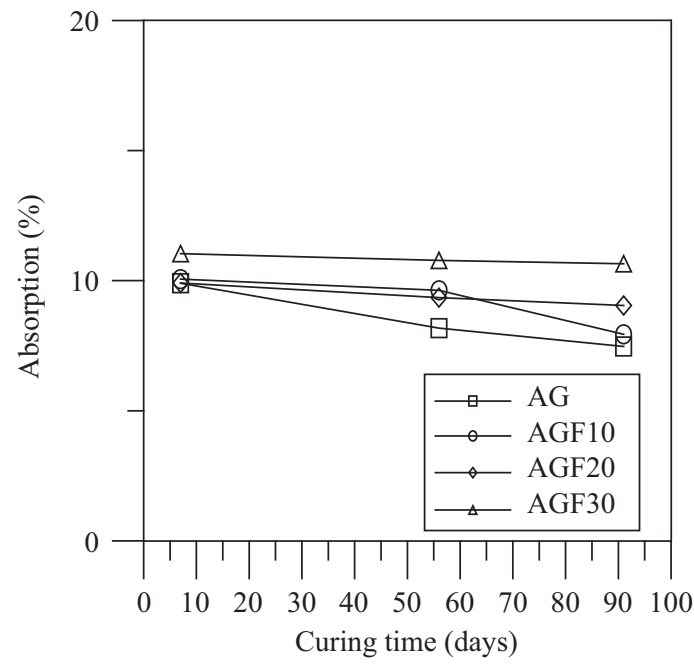

Fig. 2. Water absorption vs. time (CFBC fly ash).

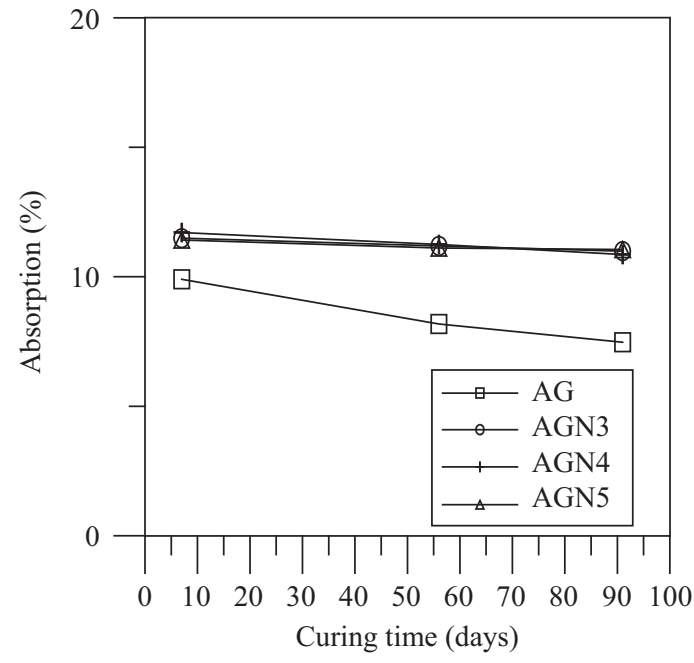

Fig. 3. Water absorption vs. time ( $\mathrm{NaOH})$.

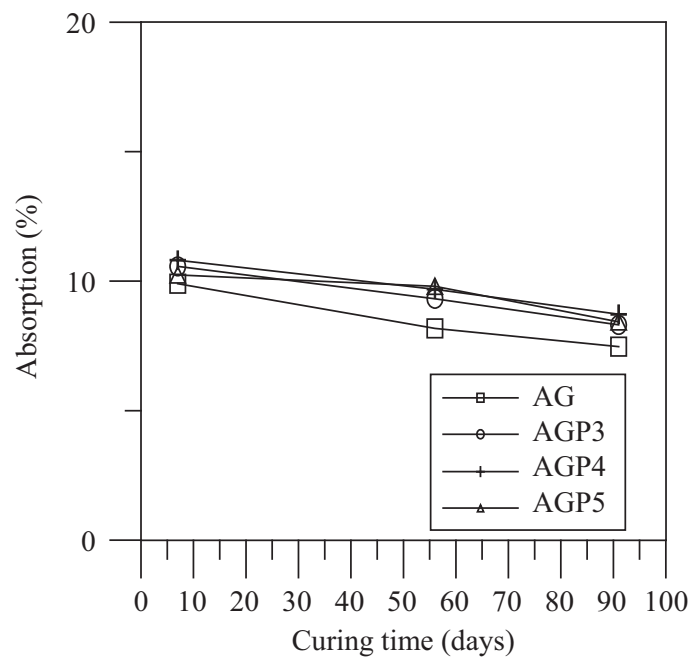

Fig. 4. Water absorption vs. time $\left(\mathrm{Na}_{3} \mathrm{PO}_{4}\right)$.

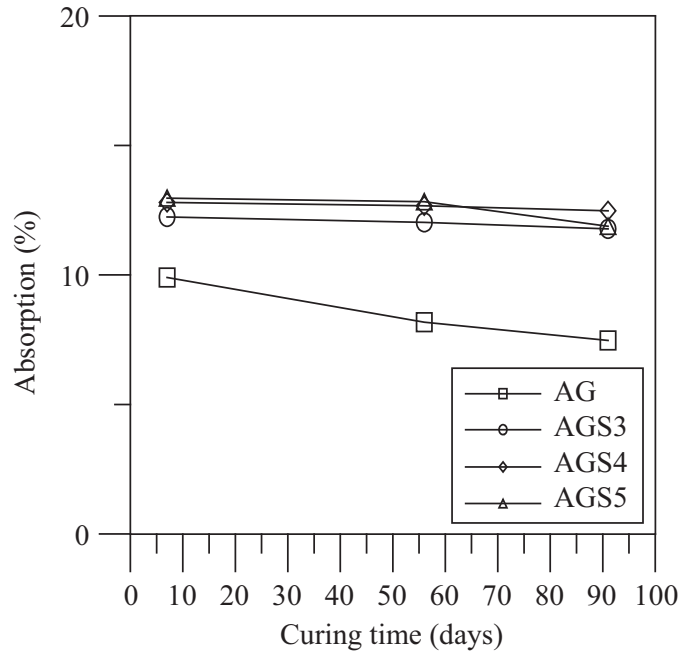

Fig. 5. Water absorption vs. time $\left(\mathrm{Na}_{2} \mathrm{SiO}_{3}\right)$

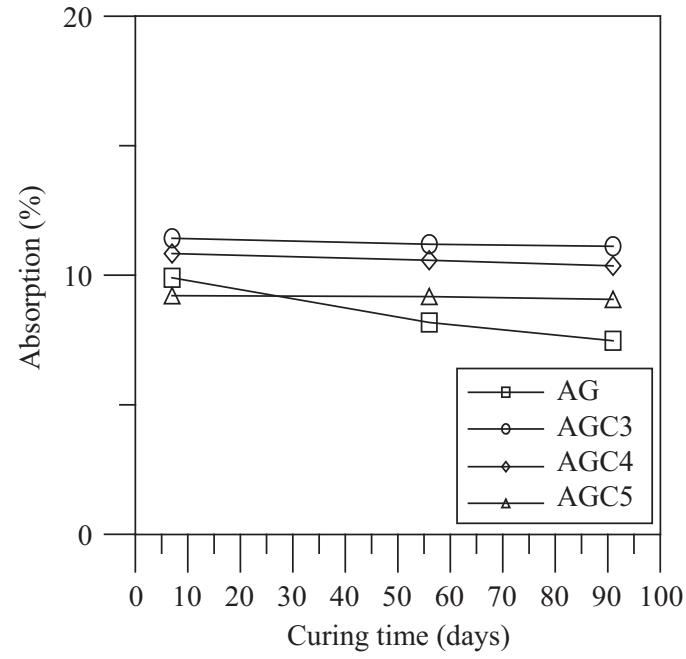

Fig. 6. Water absorption vs. time $\left(\mathrm{Na}_{2} \mathrm{CO}_{3}\right)$.

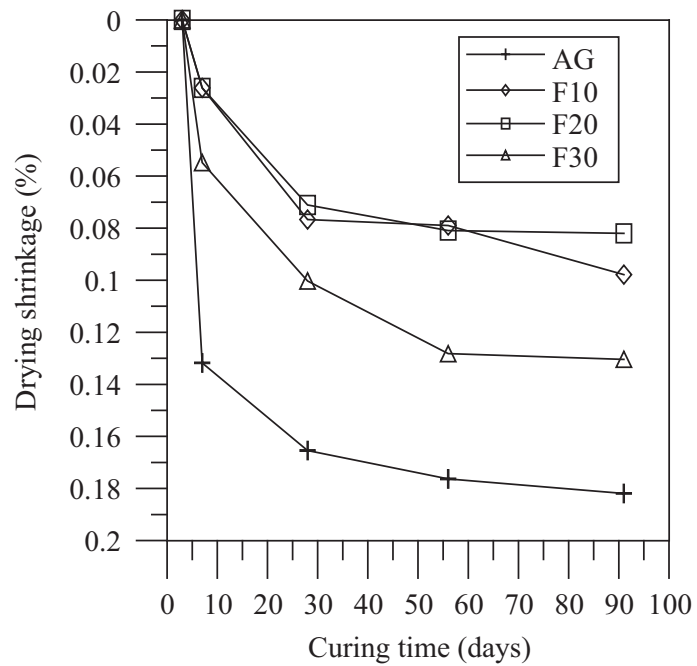

Fig. 7. Shrinkage vs. time (CFBC fly ash). 


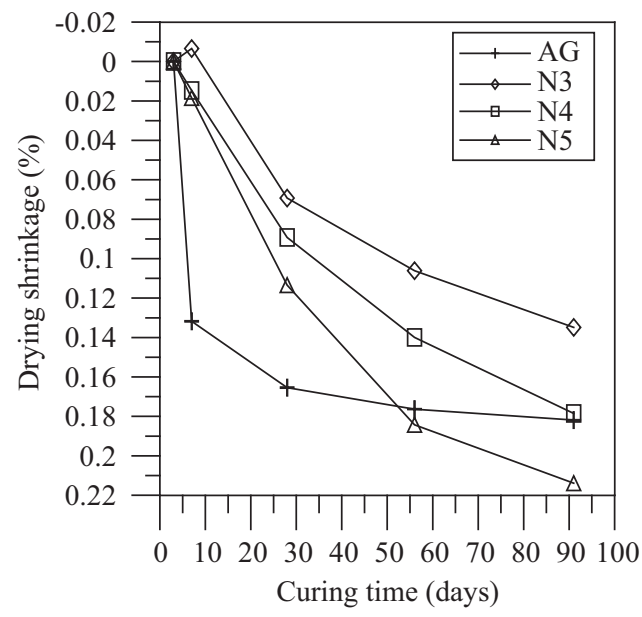

Fig. 8. Shrinkage vs. time ( $\mathrm{NaOH})$.

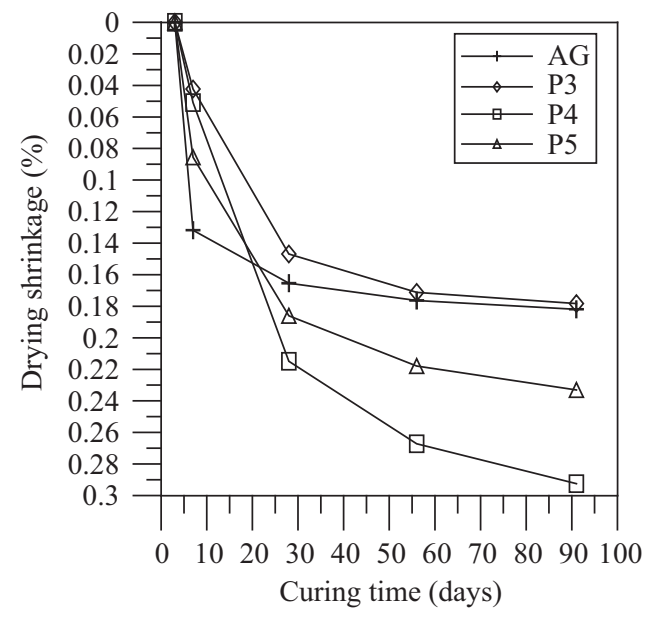

Fig. 9. Shrinkage vs. time $\left(\mathrm{Na}_{3} \mathrm{PO}_{4}\right)$.

the age increasing. The shrinkages with $3 \%$ and $4 \%$ are lower than that with $5 \%$, which exceeds the shrinkage of the control specimen at the age of 56 days. Adding $\mathrm{Na}_{3} \mathrm{PO}_{4}$, only the shrinkage with $3 \%$ specimen is close to the control specimen, the $4 \%$ and $5 \%$ specimens were much higher than the control specimen. Adding $\mathrm{Na}_{2} \mathrm{SiO}_{3}$, the shrinkage for all percentages was higher than the control specimen. The difference between themselves is also broadening with time. Adding $\mathrm{Na}_{2} \mathrm{CO}_{3}$, the shrinkage with added amounts are lower than the control specimen in the early age, whereas increasing rate became faster even higher than the control specimen for the specimen with $5 \%$ added amount.

Initial Surface Absorption. Table 4 demonstrates the initial surface absorption for the ages 7 days and 91 days. It can be seen from the Table that the initial surface absorption increased with the amount of CFBC fly ash at the age of 7 days. It is also noted that the initial surface absorption at $60 \mathrm{~min}$ is less than the control specimen. The same test results at the age of 91 days compared with the age of 7 days, merely $30 \mathrm{~min}$ instead of $60 \mathrm{~min}$ for the overturning point. Adding $\mathrm{NaOH}$,

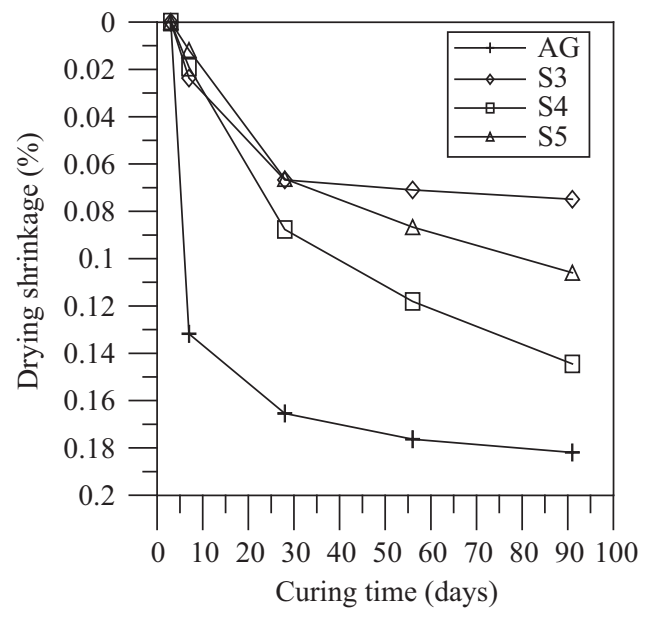

Fig. 10. Shrinkage vs. time $\left(\mathrm{Na}_{2} \mathrm{SiO}_{3}\right)$.

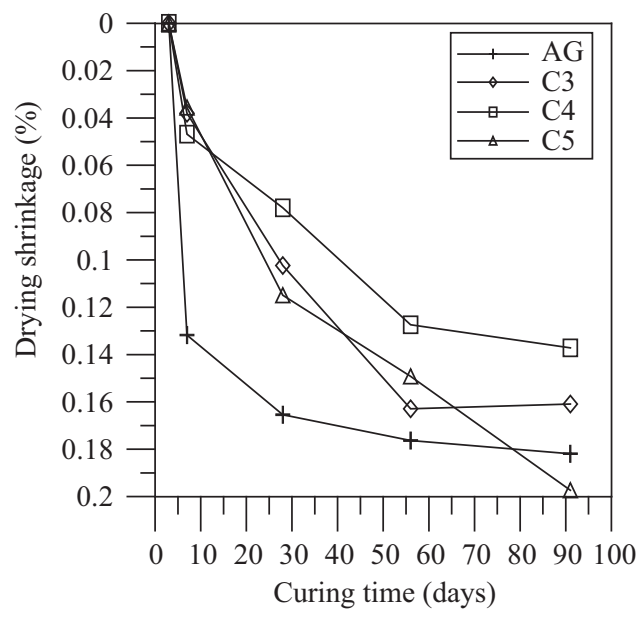

Fig. 11. Shrinkage vs. time $\left(\mathrm{Na}_{2} \mathrm{CO}_{3}\right)$.

the initial surface absorptions are much higher than the control specimen no matter at the ages of 7 days or 91 days. Adding $\mathrm{Na}_{3} \mathrm{PO}_{4}$, the initial surface absorption decreases with the amount increasing. Adding $\mathrm{Na}_{2} \mathrm{SiO}_{3}$, the initial surface absorptions are very close at the ages of 7 days and 91 days, but they are all higher than the control specimen. Adding $\mathrm{Na}_{2} \mathrm{CO}_{3}$, the initial surface absorptions at the ages of 7 days and 91 days with the amount of $3 \%$ and $4 \%$ were close, while $5 \%$ is the best and very close to the control specimen. The initial surface absorption decreases with the amount added, but all the cases provided the values higher than the control specimen.

\section{Mechanical Properties}

Compressive Strength. Figs. 12 to 16 show the compressive strength data obtained from the specimens with adding alkali activator as well as the control specimen. The major observation is that compressive strength are generally higher than the control specimen with CFBC fly ash in the early stage, while decreases with the time increasing. More specifically, adding CFBC fly ash can increase the compressive strength in 
Table 4. Initial surface absorption for the ages of 7 and 91 days.

\begin{tabular}{ccccccc}
\hline & \multicolumn{5}{c}{ Initial surface absorption rate $\left(\mathrm{ml} /\left(\mathrm{m}^{2} \times \mathrm{s}\right)\right)$} \\
\cline { 2 - 7 } Mix & \multicolumn{3}{c}{7 days } & \multicolumn{3}{c}{91 days } \\
\cline { 2 - 7 } & $10 \mathrm{~min}$ & $30 \mathrm{~min}$ & $60 \mathrm{~min}$ & $10 \mathrm{~min}$ & $30 \mathrm{~min}$ & $60 \mathrm{~min}$ \\
\hline AG & 0.685 & 0.515 & 0.445 & 0.390 & 0.330 & 0.320 \\
\hline F10 & 0.625 & 0.545 & 0.420 & 0.500 & 0.310 & 0.295 \\
F20 & 0.685 & 0.415 & 0.305 & 0.650 & 0.420 & 0.390 \\
F30 & 0.890 & 0.580 & 0.380 & 0.810 & 0.425 & 0.305 \\
\hline N3 & 1.250 & 0.865 & 0.625 & 1.260 & 0.920 & 0.810 \\
N4 & 1.480 & 0.935 & 0.695 & 1.060 & 0.690 & 0.540 \\
N5 & 1.860 & 1.070 & 0.800 & 1.200 & 0.680 & 0.560 \\
\hline C3 & 1.100 & 0.720 & 0.550 & 1.380 & 1.070 & 0.800 \\
C4 & 1.220 & 0.805 & 0.605 & 0.650 & 0.460 & 0.370 \\
C5 & 0.810 & 0.550 & 0.420 & 0.730 & 0.500 & 0.420 \\
\hline S3 & 2.120 & 1.520 & 1.160 & 1.460 & 1.000 & 0.980 \\
S4 & 2.300 & 1.570 & 1.190 & 1.90 & 1.340 & 1.040 \\
S5 & 1.860 & 1.220 & 0.880 & 1.420 & 0.950 & 0.720 \\
\hline P3 & 1.400 & 1.000 & 0.785 & 0.950 & 0.710 & 0.590 \\
P4 & 1.180 & 0.620 & 0.490 & 1.180 & 0.620 & 0.490 \\
P5 & 0.820 & 0.490 & 0.300 & 1.040 & 0.780 & 0.600 \\
\hline
\end{tabular}

the early stage and can be even higher than the control specimen. However, after 28 days, the compressive strength with $10 \%$ CFBC fly ash is almost the same with that of the control specimen, while those with $20 \%$ and $30 \%$ are lower than that of the control specimen. At the age of 56 days, the compressive strengths with $20 \%$ CFBC fly ash are close to that of the control specimen. The highest compressive strength of the specimen is that with high percentage of CFBC fly ash. The glassy compounds react slowly with water and it takes time to obtain hydroxyl ions from the hydration product of Portland cement and CFBC fly ash. The compressive strength in these mixes is attributed to both the continued hydration of Portland cement and the pozzolanic reactions. The gypsum generated from anhydrite hydration increases strength development. Cement paste hydration with higher sulfate ions produces more $\mathrm{C}-\mathrm{S}-\mathrm{H}$ and ettringite $(\mathrm{AFt})$ in hydration products. The ettringite forms from soluble calcium hydroxide, alumina, and gypsum. The reaction between sulfate ions and calcium hydroxide may sustain for ten or more years [14], therefore the strength gain takes longer for the CFBC mortar specimen. Adding $\mathrm{NaOH}$, the added amount made no clear influence on the compressive strength, which is less than half of the control specimen. Adding $\mathrm{Na}_{3} \mathrm{PO}_{4}$, the compressive strength seems to decrease in the early age and reached only $1 / 3$ of the control specimen at the long run. Adding $\mathrm{Na}_{2} \mathrm{SiO}_{3}$ and $\mathrm{Na}_{2} \mathrm{CO}_{3}$, The added amounts again made no observable difference to the compressive strength, which were about $50 \%$ of the control specimen. Based on the results described above, it is clear that only CFBC fly ash is helpful for the development of the compressive strength, while all other alkali activators reduce the compressive strength of the mortar specimens.

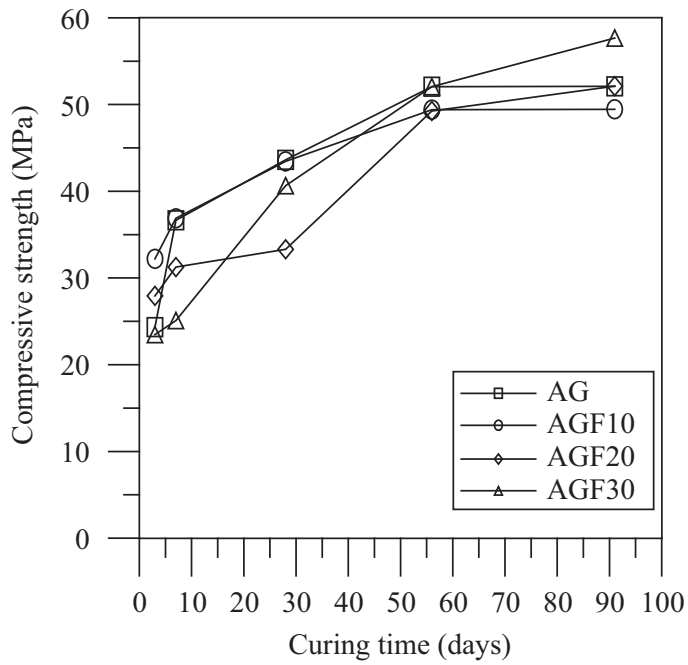

Fig. 12. Compressive strength vs. time (CFBC fly ash).

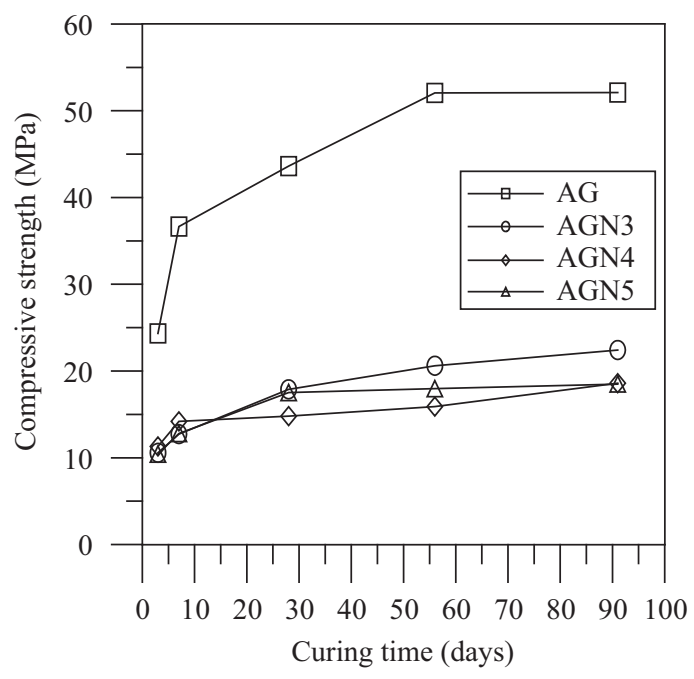

Fig. 13. Compressive strength vs. time $(\mathrm{NaOH})$.

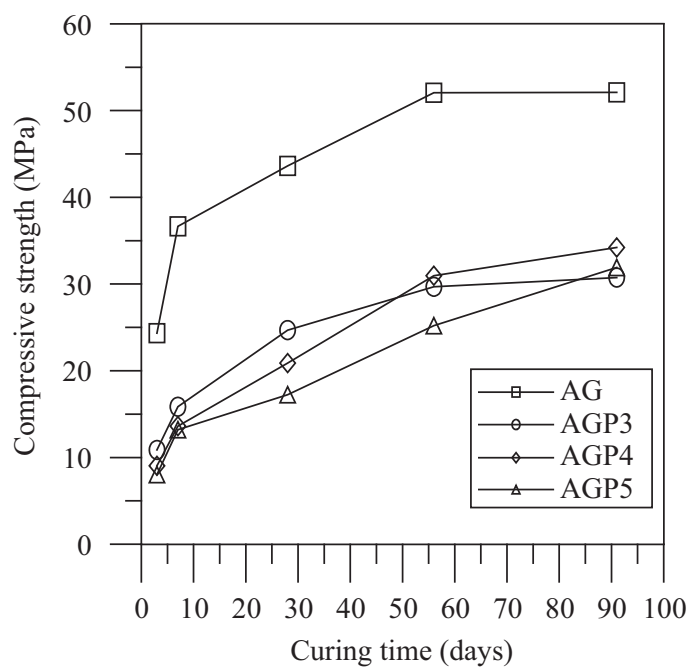

Fig. 14. Compressive strength vs. time $\left(\mathrm{Na}_{3} \mathrm{PO}_{4}\right)$. 


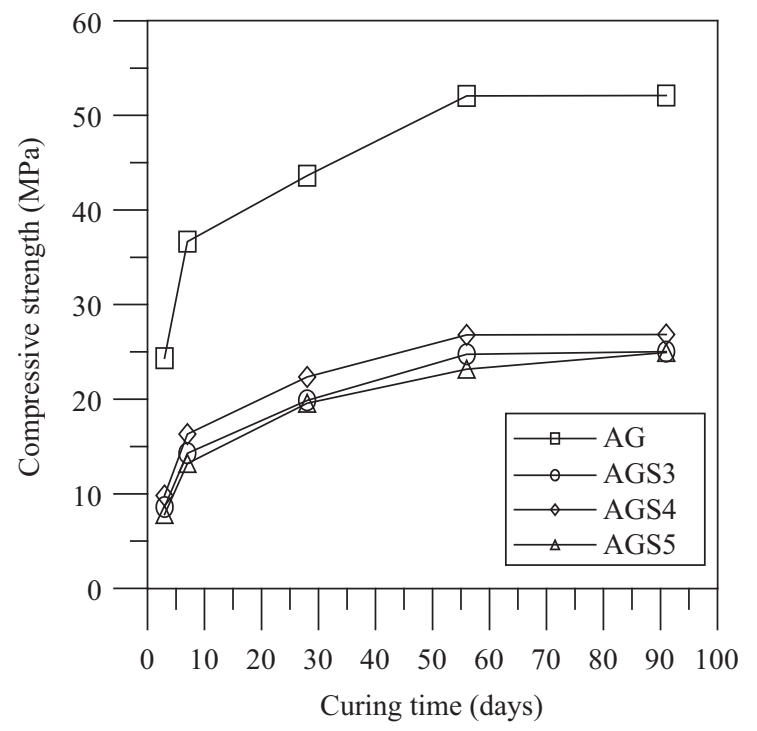

Fig. 15. Compressive strength vs. time $\left(\mathrm{Na}_{2} \mathrm{SiO}_{3}\right)$.

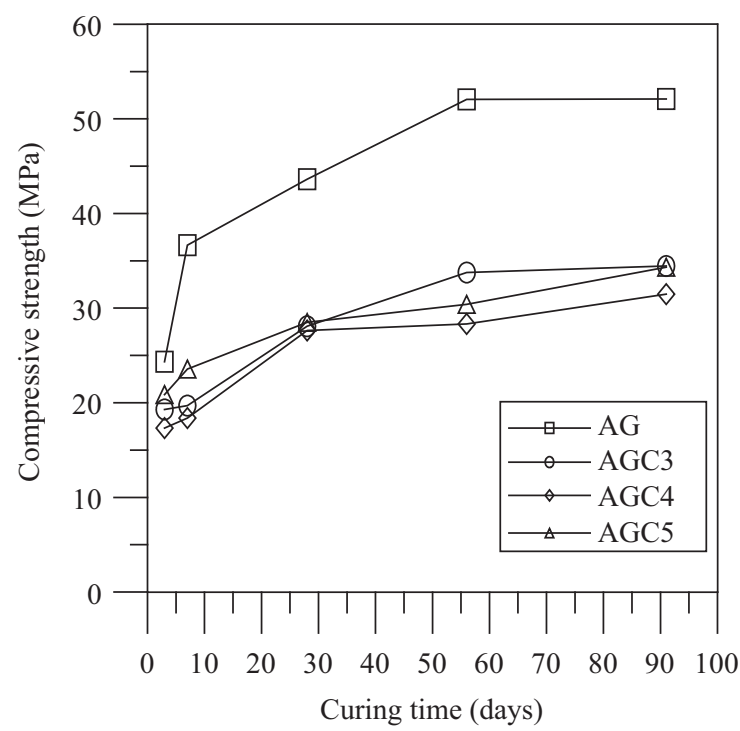

Fig. 16. Compressive strength vs. time $\left(\mathrm{Na}_{2} \mathrm{CO}_{3}\right)$.

\section{Microstructural Properties}

Porosity Measurements. The test specimen for mercury porosity test was selected from the previous most excellent result on gel development. By mercury intrusion process, the variations of the gel porosity, capillary porosity, and total porosity of the specimen with alkali activator can be observed as shown in Figs. 17 and 18, respectively, at the ages of 7 days and 91 days. From Fig. 17, it is found that the gel of the specimen with $10 \%$ CFBC fly ash developed the best at 7 days. It is also worthy to mention that the reduction of added amount of CFBC fly ash increases the compressive strength and the saturated water absorption, which are agree with this experimental results. At the age of 91 days, the development of the gel in the specimen with 20\% CFBC fly ash developed finest

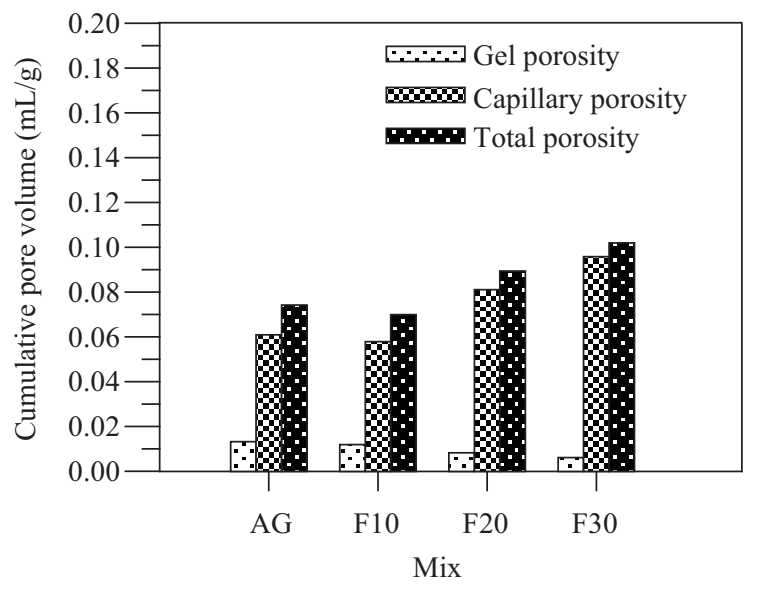

Fig. 17. Porosity distribution at 7 days.

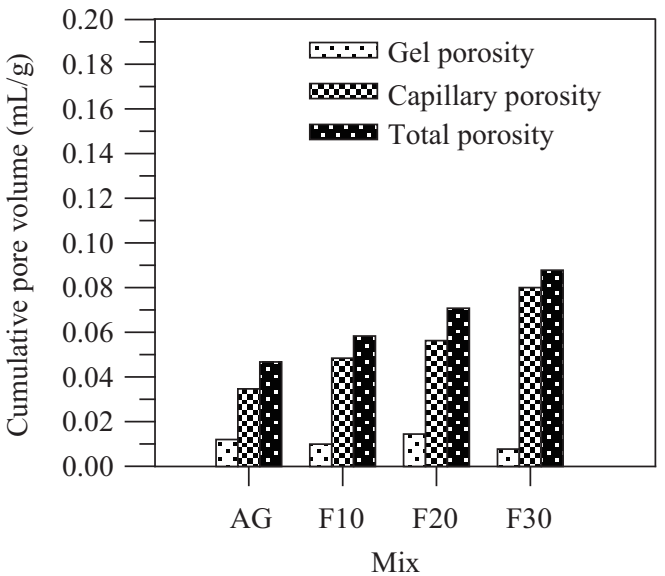

Fig. 18. Porosity distribution at 91 days.

as shown in Fig. 18, where those specimens with $10 \%$ and $30 \%$ performed close to the control specimen. The results prove that CFBC fly ash can help the development of gel pores and fill the pore effect.

SEM Observation. The specimen for SEM observation was also selected from the previous most excellent result on gel development. By scanning electron microscopy magnification of 6,000 times, the direct observation of early and late development of the C-S-H and pore structure can be realized. The SEM observation was made for the specimens with CFBC fly ash and the control specimen at 7 days and 91 days as shown in Figs. 19 to 22. It can be seen that the specimen with $10 \%$ CFBC fly ash developed more crystal of calcium hydroxide and CSH gel than the control specimen at the age of 7 days. More specifically speaking, the mortar specimen with $10 \%$ CFBC fly ash develops faster and denser than the control specimen, which is agree with the compressive strength test results. Nonetheless, the specimens with $20 \%$ and $30 \%$ CFBC fly ash developed less obvious C-S-H gel at the age of 7 days, thus the loose structure of hydration products provides little help for the early compressive strength. Furthermore, at the 


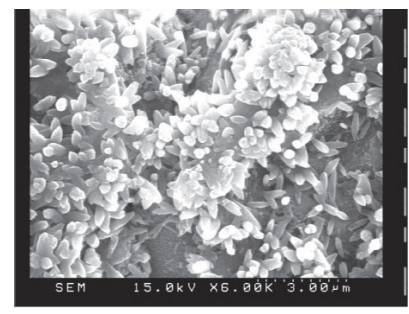

(a)

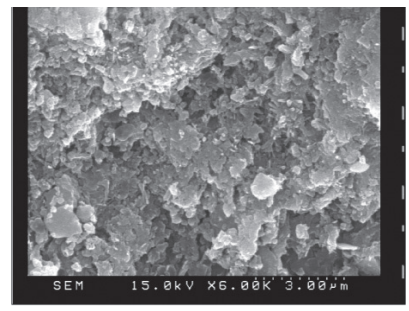

(b)
Fig. 19. SEM micrograph of the control specimen at (a) 7 days and (b) 91 days.

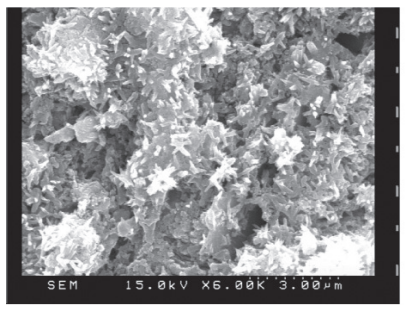

(a)

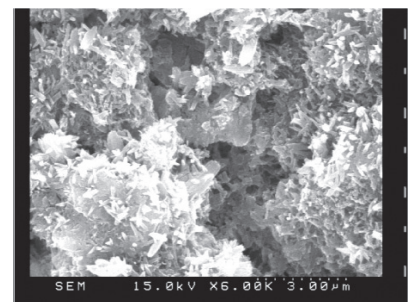

(b)
Fig. 20. SEM micrograph of the specimen with $10 \% \mathrm{CFBC}$ fly ash at (a) 7 days and (b) 91 days.

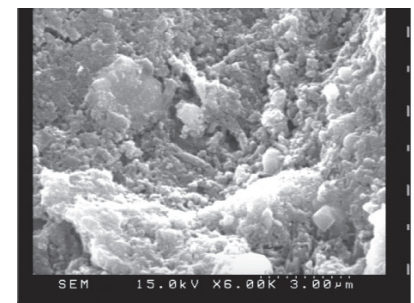

(a)

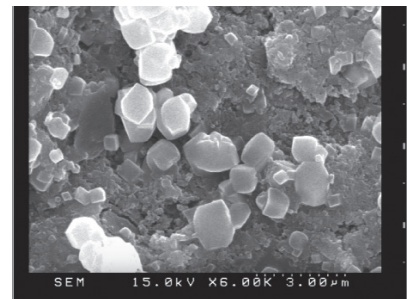

(b)
Fig. 21. SEM micrograph of the specimen with $20 \%$ CFBC fly ash at (a) 7 days and (b) 91 days.

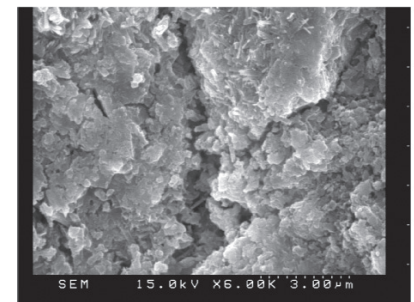

(a)

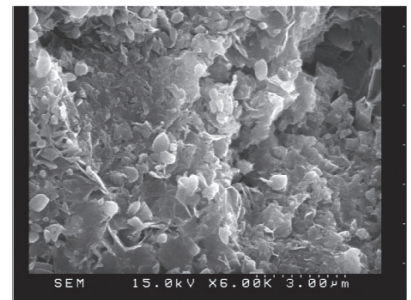

(b)
Fig. 22. SEM micrograph of the specimen with $30 \%$ CFBC fly ash at (a) 7 days and (b) 91 days.

age of 91 days, it is clear that the C-S-H gel developed completely and densely with $30 \%$ CFBC fly ash. In addition, the C-S-H gel of the specimens with $10 \%$ and $20 \%$ CFBC fly ash is similar to that of the control specimen, where also agree with the compressive strength test results.

\section{CONCLUSION}

This study illustrates the influence on mechanical properties and hydration reaction of CFBC fly ash and other alkali activators on alkali-activated slag cement mortars. The conclusions are as following:

1. Using CFBC fly ash as the alkali activator, the workability of the mortar specimen declines with the added amount of CFBC fly ash.

2. Adding CFBC fly ash, the bleed water reduces with the amount used.

3. Adding CFBC fly ash as the alkali activator, the effect of setting time reduction is quite apparent.

4. Adding CFBC fly ash, the water absorption increase with the amount added. The water absorption for $10 \%$ CFBC fly ash specimen is close to the value of control specimen.

5. Adding CFBC fly ash, the drying shrinkage with all kinds of percentages are lower than the control specimen. Thus, it can be supposed that adding alkali activators is helpful for the purpose of shrinkage reduction.

6. Initial surface absorption does not increase or decrease much with the added amount of CFBC fly ash.

7. Adding $10 \%$ CFBC fly ash can increase the compressive strength in the early phase. However, the compressive strength with $20 \%$ and $30 \%$ CFBC fly ash are lower than that of the control specimen.

8. It is summarized that the specimens with CFBC fly ash developed more crystal of calcium hydroxide and C-S-H gel, where not only develop much more completely and densely themselves but also agree with the compressive strength test results.

\section{REFERENCES}

1. ASTM C109/C109M-08, Standard Test Method for Compressive Strength of Hydraulic Cement Mortars.

2. ASTM C150/C150M-09, Standard Specification for Portland Cement.

3. ASTM C232 - 07 Standard Test Methods for Bleeding of Concrete.

4. ASTM C403/C403M-08, Standard Test Method for Time of Setting of Concrete Mixtures by Penetration Resistance.

5. ASTM C596-09, Standard Test Method for Drying Shrinkage of Mortar Containing Hydraulic Specimens.

6. ASTM C642-97, Standard Test Method for Density, Absorption, and Voids in Hardened Concrete.

7. ASTM D4404-84, Standard Test Method for Determination of Pore Volume and Pore Volume Distribution of Soil and Rock by Mercury Intrusion Porosimetry.

8. ASTM D6103-04, Standard Test Method for Flow Consistency of Controlled Low Strength Material (CLSM).

9. BS 1881, Recommendations for the Determination of the Initial Surface Absorption of Concrete.

10. Collins, F. and Sanjayan, J. G., "Effect of pore size distribution on drying shrinkage properties of alkali-activated slag concrete," Cement and Concrete Research, Vol. 30, pp. 1401-1406 (2000).

11. Conn, R. E. and Sellakumar, K., "Utilization of CFB fly ash for construction application," Proceedings of the 15th International Conference on Fluidized Bed Combustion, Savannah, Georgia (1999).

12. Davidovits, J., "Synthetic mineral polymer compound of the cilicoaluminates family and preparation process," U.S. Patent 4472199 (1981). 
13. Gong, C. and Yang, N., "Effect of phosphate on the hydration of alkali-activated red mud-slag cementitious material," Cement and Concrete Research, Vol. 30, pp. 1013-1016 (2000).

14. Mindess, S., Francis, Y. J., and Darwin, D., Concrete, $2^{\text {nd }}$ Ed, Prentice Hall, NJ (2002).
15. Purdon, A. O., "The action of Alkalis on blast-furnace slug," Journal of the Society of Chemical Industry, Vol. 59, pp. 191-202 (1940).

16. Sheng, G. and Zhai, J., "Utilization of fly ash coming from a CFBC boiler co-firing coal and petroleum coke in Portland cement," Fuel, Vol. 86, No. 16 , pp. 2625-2631 (2007). 